\title{
Świadomość prawna a motywacje osób składających skargę na swoje małżeństwo
}

Zmiany zachodzące w społeczeństwie polskim relatywizują instytucję małżeństwa, coraz częściej także w środowisku katolickim rozmywają się jej konstytutywne przymioty, którymi są jedność i nierozerwalność (kan. 1056 KPK ${ }^{1}$ ). Sytuację kryzysu małżeństwa odzwierciedla wzrastająca ilość orzeczeń rozwodów - w Polsce od kilku lat ich liczba przekracza rocznie 60 tysięcy². Problem ten dotyczy w dużej mierze małżeństw katolickich, stanowiących przykładowo w 2014 roku około 63 proc. wszystkich zawartych małżeństw³ ${ }^{3}$ Statystyki Kościoła katolickiego wskazują także, że liczba orzeczeń nieważności małżeństw w Polsce systematycznie wzrasta ${ }^{4}$. Małżeństwo katolików nie jest instytucją prywatną,

1 Codex Iuris Canonici auctoritate Ioannis Pauli PP. II promulgatus, AAS 75 (1983), cz. 2, s. 1-318, tłum. z przekładu zatwierdzonego przez Konferencję Episkopatu Polski, Kodeks prawa kanonicznego, tekst łacińsko-polski, Poznań 1984.

2 Rocznik Demograficzny, Warszawa 2014, s. 32; 2013-66,1 tys.; 2010 - 61,3 tys.; 2006 - 71,9 tys.; 2001 - 45,3 tys.

3 Rocznik Demograficzny, Warszawa 2014; małżeństw wyznaniowych w Kościele katolickim w 2013 roku zawarto 113 612, ogólna liczba małżeństw zawartych w 2013 wyniosła 180396.

4 Rocznik Statystyczny, Kościół katolicki w Polsce 1991-2011, Warszawa 2014, s. 176 (1989 - 807, 2001 - 1 490, 2006 - 1 843, 2010 - 2 235; dane Annuarium Statisticum Ecclesiae 1989-2010); liczba spraw o nieważność małżeństwa wniesio- 
podlega bowiem prawu Bożemu oraz kanonicznemu, natomiast określone kompetencje odnośnie do cywilnych skutków tegoż małżeństwa posiada także ustawodawca państwowy (kanon 1059 КРК). Nie należy jednak w każdej sytuacji rozpadu małżeństwa na płaszczyźnie prawa świeckiego doszukiwać się nieważności małżeństwa zawartego w Kościele katolickim.

Papież Benedykt XVI w przemówieniu do Roty Rzymskiej w 2007 roku zwrócił uwagę na kształtowanie się przekonania, że „z duszpasterskiego punktu widzenia dobro osób żyjących w nieregularnych sytuacjach małżeńskich wymaga jakiegoś kanonicznego uregulowania, niezależnie od ważności czy nieważności ich małżeństwa, a więc niezależnie od «prawdy» o ich sytuacji osobistej”. Papież w dalszej wypowiedzi stwierdził, że w takim kontekście proces staje się narzędziem prawnym do realizacji subiektywnych celów, czyli roszczeń. W istocie celem procesu kanonicznego jest „określenie i ochrona dóbr należnych osobom i instytucjom”. Wierny posiada prawo do legalnego dochodzenia, a także obrony uprawnień przysługujących mu na właściwym forum kościelnym według przepisów prawa, co zostało ustanowione przez prawodawcę w kan. 221 §1 Kodeksu prawa kanonicznego. W procesie orzeczenia o ważności lub nieważności małżeństwa, dotyczącego nie tylko samych małżonków, ale Kościoła i społeczeństwa7 ${ }^{7}$, przedmiotem jest prawda stanowiąca fundament instytucji małżeństwa.

nych do sądów kościelnych w roku 2013 wyniosła: 3164, orzeczeń o nieważności małżeństwa w drugiej instancji w 2013 było 2611, http://www.iskk.pl/news/78malzenstwa.html (13.03.2016).

5 Benedykt xVI, Piękno prawdy o matżeństwie, objawionej przez Chrystusa. Przemówienie do Roty Rzymskiej 27 stycznia 2007 r., „L'Osservatore Romano”, wyd. pol., 293 (2007), s. 31-32.

6 Benedykt XVI, Umiłowanie prawdy a proces o nieważność małżeństwa. Przemówienie do pracowników Trybunału Roty Rzymskiej 28 stycznia 2006 r., „L’Osservatore Romano", wyd. pol., 282 (2006) 4, s. 28-30.

7 Benedykt XVI, Umiłowanie prawdy..., art. cyt. 
Poszukiwanie prawdy o małżeństwie w procesie sądowym jest realizacją obowiązku - nałożonego przez Kościół na wszystkich ludzi - szukania „prawdy dotyczącej Boga i Jego Kościoła, a poznane mają obowiązek i prawo z mocy prawa Bożego przyjąć i zachowywać" (kan. 748 §1 кPK).

Uprawnieni do złożenia skargi powodowej na małżeństwo są sami małżonkowie katoliccy lub/i niekatoliccy. W sytuacji gdy nieważność małżeństwa została rozgłoszona, skargę może złożyć także rzecznik sprawiedliwości (kan. 1476 i kan. 1674 §2 КРк). Zasadniczo jednak skarga ta jest składana przez nielicznych rozwiedzionych małżonków, pojawia się zatem pytanie o brak motywacji tych małżonków, którzy nie podejmują próby weryfikacji ważności swojego kanonicznego małżeństwa, przynajmniej w celu upewnienia się co do swojej sytuacji. W artykule jednak zostanie omówione zagadnienie motywacji do czynności prawnych osób, które już złożyły skargę na małżeństwo w sądzie biskupim, celem jest przyjrzenie się tym czynnikom, które stanowiły bodziec do podjęcia czynności zmierzających do uregulowania sytuacji w Kościele. Natomiast rozważanie nad świadomością prawną w zakresie orzeczenia nieważności małżeństwa, podjęte w drugiej części pracy, stanowi wstęp do szerszej refleksji nad komunikacją między prawodawcą a wiernym w Kościele katolickim. Omówione elementy świadomości prawnej mają na celu przybliżenie istotnych obszarów kształtujących stosunek wiernego do prawa kanonicznego.

\section{1. Świadomość prawna a motywacja stosowania prawa}

Pojęcie świadomości prawnej służy do opisu relacji pomiędzy człowiekiem a prawem ${ }^{8}$. Zainteresowanie społecznym działaniem

8 F. Fleerackers, Affective legal analysis: on the resolution of conflict, Berlin 2000, s. 15 . 
prawa zrodziło się w latach dwudziestych dwudziestego wieku i początkowo ukierunkowane było na motywacyjną i wychowawczą funkcję prawa. Prekursorem tej myśli był Leon Petrażycki, który stworzył podwaliny nowoczesnej wiedzy o motywacji ludzkiego postępowania9. W ciągu kilkudziesięciu lat powstały różne koncepcje świadomości prawnej, między innymi rozumiano ją jako „całokształt ocen odnoszących się do obowiązujących lub postulowanych instytucji politycznych i prawnych, ocen, które opierają się na pewnej znajomości prawa, znajomości jego zastosowania oraz co najmniej elementarnym rozeznaniu w funkcjonowaniu instytucji politycznych”». Świadomość prawna wyrasta nie tylko z refleksji nad prawem świeckim, choć tam wykształciły się jej szczegółowe koncepcje, ale także budowana była na gruncie prawa kościelnego; towarzyszyła Kościołowi od początku jego istnienia, wraz z kształtującym się prawem kanonicznym.

\subsection{Motywacja do stosowania i przestrzegania norm prawnych}

Leon Petrażycki zwrócił uwagę na związek świadomości prawnej z rodzącymi się emocjami stanowiącymi motywację do podejmowania działań prawnych. Interesowały go motywy postępowania w perspektywie moralnej i prawnej, ponieważ związane są one z sytuacjami, w których na człowieku ciąży poczucie jakiegoś obowiązku. Na przykładzie stosunku człowieka do obowiązku wyznaczył podział między świadomością moralną a świadomością prawną. W pierwszym wypadku zachodzi relacja jednostronnie imperatywna, podmiotem prawa na płaszczyźnie moralnej jest wyłącznie obowiązany. Obowiązki te nie mają roszczenia,

9 A. Kojder, Wstęp, [w:] L. Petrażycki, O pobudkach postępowania i o istocie moralności i prawa, Warszawa 2002, s. 28.

1o S. Ehrlih, Wstęp do nauki o państwie i prawie, Warszawa 1971, s. 259. 
to znaczy nikt nie może oczekiwać, że obowiązkiem jakiejś osoby jest właśnie wykonanie danej czynności, i nikt nie może tego od niej żądać. Świadomość prawna z kolei jest zawsze dwustronna, występuje w niej strona mająca obowiązek i strona mająca prawo do tego obowiązku, czyli roszczenie. Świadomość prawną Petrażycki nazywał imperatywno-atrybutywną".

Świadomość moralna przekształca się w świadomość prawną wówczas, gdy świadomość towarzysząca określonemu postępowaniu z przekonania, że coś jest „dobre i godne zalecenia”, ulega przemianie na przekonanie, że niewykonanie tej czynności oznacza odebranie komuś czegoś, co mu przysługuje. Pisząc o tym Petrażycki odwołał się między innymi do ewolucji etyki chrześcijańskiej, która opiera się na zasadach moralnych przenikających do różnych systemów prawnych, ewoluując w normy prawne. Takie przemiany według Petrażyckiego oznaczają postęp społeczny, bowiem przyczyniają się do upowszechniania sposobu postępowania rzadko praktykowanego, lecz społecznie bardzo pożądanego ${ }^{12}$.

Gdy podejmuje się refleksję nad świadomością prawa w optyce prawa kanonicznego, konieczne wydaje się poruszenie kwestii świadomości moralnej, ponieważ jest ona znacząca w badaniu zachowań wiernych w obrębie prawa kościelnego. Świadomość moralna zawiera w sobie podobne treści jak świadomość prawna: wiedzę, poglądy, przekonania, pojęcia wyobrażenia oraz uczucia i postawy. Świadomość moralna ujmowana jest jako zjawisko dynamiczne, zmieniające się w kontekście historycznym, stąd też ocenianie stopnia świadomości musi być dokonywane w perspektywie rozwoju jednostki i społeczeństwa ${ }^{13}$. Sam Leon Petrażycki sytuował prawo nie tylko w wymiarze społecznym, ale przede

\footnotetext{
11 L. Petrażycki, O pobudkach postępowania..., dz. cyt., s. 76-78.

12 L. Petrażycki, O pobudkach postępowania..., dz. cyt., s. 76-78.

13 J. Mariański, Moralność w kontekście społecznym, Kraków 2015, s. 21. Zob. M. Ossowska, Socjologia moralności, Warszawa 2005, s. 104.
} 
wszystkim w psychicznej sferze człowieka, rozumiejąc je jako przeżycie psychiczne osoby ${ }^{14}$. Dlatego też analiza świadomości prawnej powinna uwzględniać także rozwój moralny człowieka. W literaturze można znaleźć odwołania do koncepcji rozwoju moralnego, autorstwa Lawrensa Kohlberga, wykorzystywanej do określenia stadiów myślenia o moralności i prawie ${ }^{15}$. Kohlberg wytyczył trzy poziomy rozwoju moralnego: konwencjonalny, przedkonwencjonalny oraz pokonwencjonalny, stopniowane według orientacji osoby ku jakiemuś dobru, takiemu jak: „orientacja na karę i posłuszeństwo, orientacja instrumentalno-egoistyczna, orientacja podobania się, orientacja na prawo i porządek, orientacja legalistyczna albo umowy społecznej, orientacja na zasady ogólnie przyjęte"16.

Współcześnie uznaje się, że uwzględnienie motywacji w badaniu świadomości prawnej jest nieodzowne, gdyż wyznacza treść świadomości prawnej ${ }^{17}$. W opinii innych autorów jednak oba zjawiska powinny być badane osobno, pomimo że niezaprzeczalnie istnieje między nimi wzajemność ${ }^{18}$. Motywacja nie jest elementem świadomości prawnej, ale może mieć znaczenie w odczytaniu stosunku jednostki do norm, szczególnie do wartości, które są prawnie chronione ${ }^{19}$. Z drugiej strony, dostrzega się także odwrotną sytuację: to sposób rozumienia przez jednostkę norm prawnych i norm moralnych wpływa na to, czy motywacja jest prawna, czy moralna, lub też czy jednostka kieruje się obiema motywacjami.

14 L. Petrażycki, O pobudkach postępowania..., dz. cyt., s. 76-78.

15 M. Borucka-Arctowa, G. Skąpska, Teoretyczne problemy socjalizacji prawnej, [w:] Socjalizacja prawna, red. M. Borucka-Arctowa, Ch. Kourilsky, Warszawa 1993, S. 21.

16 J. Mariański, Moralność..., dz. cyt., s. 47-49.

17 A. Gryniuk, Świadomość prawna. Studium teoretyczne, Toruń 1979, s. 9.

18 Z. Cywiński, Kilka uwag o ujęciach świadomości prawnej, „Studia Iuridica” XXXI (1996), s. 20.

19 A. Gryniuk, Świadomość prawna...., dz. cyt., s. 9. 
Istotne znaczenie dla określenia rodzaju motywacji ma rozróżnienie norm moralnych i prawnych, którego dokonuje jednostka, szczególnie uwzględniając trudność związaną z krzyżowaniem się tych norm w życiu społecznym ${ }^{20}$.

Zygmunt Ziembiński i Sławomira Wronkowska wyróżnili dwa rodzaje motywacji do wypełniania norm prawnych. Pierwszą z nich była motywacja ,interesowna”, wynikająca z obawy przed sankcją zinstytucjonalizowaną, naruszającą interesy oraz prestiż adresata prawa $^{21}$. Ten rodzaj motywacji może być związany z postawą legalistyczną wobec prawa, coraz częstszą w atomizującym się społeczeństwie. Jednostka tracąc wpływ na społeczeństwo, chroni się w małych grupach, w których może doświadczyć poczucia bezpieczeństwa, zwalniając się tym samym z poczucia odpowiedzialności za całość społeczeństwa. Konsekwencją tej postawy jest mentalność roszczeniowa ${ }^{22}$. Drugą wyróżnioną motywacją była motywacja „bezinteresowna”, zakładająca akceptację normy ze względu na jej słuszność, a nie z obawy przed sankcją, bowiem prawo należy przestrzegać niezależnie od sankcji ${ }^{23}$. Podejmując zagadnienie motywacji do stosowania lub przestrzegania prawa, należy więc mieć na uwadze motywację wynikającą z pobudek prawnych oraz moralnych.

\subsection{Motywacja do stosowania prawa w Kościele katolickim}

W Kościele katolickim związek prawa i moralności ma szczególny charakter. Przyjmuje się, że norma prawna jest zobowiązaniem prawnym i moralnym, czyli wiąże w sumieniu adresata normy, jednak jak

20 A. Podgórecki i in., Poglądy spoteczeństwa polskiego na moralność i prawo, Warszawa 1971, s. 32.

21 Z. Ziembiński, S. Wronkowska, Zarys teorii prawa, Poznań 2001, s. 198.

22 R. Sobański, Moralność i prawo, „Śląskie Studia Historyczno-Teologiczne” 32 (1999), s. 168.

23 Z. Ziembiński, S. Wronkowska, Zarys teorii..., dz. cyt., s. 198. 
pisał ks. prof. Remigiusz Sobański, „motywacje prawne czy etyczne nie muszą się pokrywać” w stosowaniu ustawy kościelnej, bowiem obowiązuje ona niezależnie od jej akceptacji. Wierny może stosować ustawę tylko ze względu na jej moc prawną - „po prostu ze «względu na prawo»", natomiast etycznej motywacji, rozumianej w znaczeniu chrześcijańskim, domaga się wyłącznie obowiązek moralny ${ }^{24}$.

Motywacja legalistyczna najczęściej przypisywana jest stosowaniu norm, które są obwarowane sankcjami, przy czym wierny może nie akceptować przestrzeganego czy stosowanego prawa. Natomiast w przypadku norm niemających sankcji prawnych - według ks. prof. R. Sobańskiego - stosowanie ich przez wiernego może „sprowadzać się do lojalności wobec prawodawcy, do przekonania o konieczności zachowania porządku publicznego i unikania zgorszenia, do chęci dostosowania się do praktyki wspólnoty" ${ }^{25}$. Zwraca się także uwagę na to, że samemu prawodawcy kościelnemu jednak zależy na tworzeniu takich ustaw, które będą stosowane i akceptowane przez wspólnotę ${ }^{26}$. Należy podkreślić, że motywacja prawna lub moralna nie mają znaczenia dla formalnego przebiegu procesu o nieważność małżeństwa. Ich określenie może służyć do interpretacji stosunku adresata normy do prawa oraz dawać wskazówki do formułowania postulatów wobec prawa oraz praktyki duszpasterskiej.

24 R. Sobański, Nauki podstawowe prawa kanonicznego. Teoria prawa kanonicznego, Warszawa 2001, s. 107.

25 R. Sobański, Nauki podstawowe..., dz. cyt., s. 123-124.

26 P. Kroczek, Kiedy prawo kanoniczne jest efektywne?, „Annales Canonici” 2 (2006), s. 171. 


\subsubsection{MOTYWACJA OSÓB SKŁADAJĄCYCH SKARGĘ NA MAŁŻEŃ-} STWO W KOŚCIELE KATOLICKIM ${ }^{27}$

Warto zatem przyjrzeć się, jaką motywację deklarowały osoby składające skargę na małżeństwo w sądzie kościelnym. Zrobimy to na przykładzie 30-osobowej grupy badawczej, w tym 17 kobiet i 13 mężczyzn w wieku między 24. a 50. rokiem życia. Wśród badanych wykształcenie wyższe miało 12 osób, 13 osób miało wykształcenie średnie, a 5 osób wykształcenie zawodowe. 18 osób mieszkało w mieście, natomiast pozostałe 12 na wsi. W przypadku 20 osób od ich rozwodu upłynęło 2 do 6 lat, pozostałe osoby były rozwiedzione od 7 do 16 lat. Osiemnaścioro badanych osób było $\mathrm{w}$ związku formalnym lub nieformalnym z nowym partnerem, z czego w większości przypadków związek ten trwał od 7 do 11 lat. Respondentów zapytano także o potomstwo; 15 osób nie posiadało dziecka z małżeństwa rozwiedzionego, natomiast potomstwo z drugiego związku miało 17 osób.

Powyższa charakterystyka socjodemograficzna wskazuje na znaczące kwestie kształtujące prawnokanoniczną sytuację katolików po rozwodzie, wpływające na podjęcie czynności procesowych przez osoby. Wymienione sytuacje pociągają za sobą określone konsekwencje prawne oraz moralne. Katechizm Kościoła katolickiego ${ }^{28}$ stanowi, że rozwód jest poważnym naruszeniem prawa naturalnego, narusza także godność sakramentu małżeństwa (KKK 2384), natomiast „niemoralny charakter rozwodu

27 Badania przeprowadzone w ramach pracy licencjackiej pt. Motywy osób zaskarżających małżeństwo przed sądem kościelnym, obronionej przez Urszulę Miernik w 2012 na Uniwersytecie Jana Pawła II w Krakowie. Badania osób składających skargę na małżeństwo w sądzie kościelnym były przeprowadzone w latach 2011-2012 w sądzie biskupim w archidiecezji krakowskiej oraz diecezji bielsko-żywieckiej. Z uwagi na niereprezentatywność grupy badawczej wnioski z badań nie mają charakteru ogólnego.

28 Katechizm Kościoła katolickiego, Poznań 2004. 
wynika z nieporządku, jaki wprowadza on w komórkę rodzinną i w społeczeństwo. Nieporządek ten pociąga za sobą poważne szkody: dla porzuconego współmałżonka, dla dzieci, które doznały wstrząsu z powodu rozejścia się rodziców, często starających się pozyskać ich względy, oraz z uwagi na zły przykład, który czyni z niego prawdziwą plagę społeczną" (KKK 2385). W ocenie moralnej uwzględnia się także winę osoby, która porzuciła małżonka, oraz niewinność tej, która została porzucona (KKK 2386). Rozwód cywilny posiada konsekwencje w prawie Kościoła katolickiego, dotyczą one dwóch istotnych aspektów: niemożliwości zawarcia małżeństwa kanonicznego bez orzeczenia nieważności małżeństwa, które zostało rozwiązane na płaszczyźnie cywilnej, oraz niemożliwość przystąpienia do sakramentu komunii świętej (kan. 915 KPK) 29.

Deklarowana motywacja osób składających skargę na swoje małżeństwo bardzo często związana była z wiarą, pragnieniem życia we wspólnocie Kościoła zgodnie z jego prawem. W wypowiedziach respondentów znalazły się między innymi następujące powody złożenia skargi: „chęć uporządkowania swojej sytuacji w Kościele”, „chęć życia zgodnego z wiarą”, „korzystania z sakramentów"; pojawiły się także stwierdzenia o lęku z powodu życia w grzechu. Motywacją do działań prawnych było dla większości badanych dobro potomstwa: rodzice poczuwali się do odpowiedzialności za wychowanie dzieci zgodne z wiarą, także wypowiadali się, że chcieliby przystąpić do sakramentów w czasie Pierwszej Komunii Świętej swoich dzieci. Kolejny motyw, który był istotny dla większości badanych, dotyczył możliwości zawarcia małżeństwa kościelnego z osobą, z którą składający skargę jest w związku

29 Zob. szerzej P. Steczkowski, Dopuszczenie rozwiedzionych $i$ żyjących $w$ nowych zwiq̨zkach do komunii świętej. Forum eksternum czy forum internum?, „Annales Canonici" 4 (2008), s. 83-97. 
formalnym lub nieformalnym. Podobnie wyrażały się osoby żyjące samotne: ,jeśli w przyszłości miałabym założyć rodzinę, to nie wyobrażam sobie żyć w związku cywilnym”, „moją motywacją jest wiara w to, że spotkam w przyszłości na mojej drodze odpowiedniego człowieka dojrzałego do miłości i małżeństwa i że po stwierdzeniu nieważności małżeństwa (jak Pan Bóg pozwoli) wyjdę za mąż i będę w związku sakramentalnym”.

W badaniach zapytano respondentów także o oczekiwania związane z uzyskaniem orzeczenia nieważności małżeństwa. Niemalże dla wszystkich badanych bardzo ważna lub ważna była możliwość korzystania z sakramentów. Uporządkowanie swojej sytuacji w Kościele nie było ważne tylko dla jednej osoby. Uzyskanie orzeczenia o nieważności małżeństwa 23 osobom może przynieść uspokojenie sumienia. W podjęciu decyzji o złożeniu skargi w różnym stopniu uczestniczyły także osoby bliskie respondentom, takie jak obecny partner, przyjaciele, rodzina czy ksiądz; nieliczne osoby uznały, że jest dla nich ważne spełnienie oczekiwań bliskich w wyjaśnieniu sytuacji ich małżeństwa. Kolejne pytanie dotyczyło tego, czy orzeczenie nieważności rozumiane jako odcięcie się od przeszłości jest ważne - za takie oraz za bardzo ważne uznało je 15 osób. Nadzieja zawarcia małżeństwa sakramentalnego w przyszłości była bardzo ważna oraz ważna dla 28 badanych osób, dla pozostałych nie było to ważne lub nie miały zdania na ten temat.

W przedstawionych wypowiedziach czynniki motywacyjne są powiązane z wyznawaną religią oraz normami kościelnymi. Trudno jednak określić jednoznacznie, czy te motywy są wyłącznie moralne, czy także prawne; wnioski te raczej obrazują stwierdzenie, że prawo i wiara w Kościele przenikają się wzajemnie, bowiem w życiu chrześcijanina to „praktyka wiary stanowi [...] także doświadczenie prawa, praktyka zaś prawa jest doświadczeniem 
wiary"3o. Prawo kanoniczne motywuje tę praktykę chrześcijanina. Jednakże świadomość powołania wiernego do dawania świadectwa wiary nie jest równoznaczna ze świadomością prawnąą1. Stąd też może istnieć trudność w zdefiniowaniu pojęcia świadomości prawnej. Konieczne jest zatem przyjęcie kryteriów, według których będzie można określić, jaki kształt może przybierać świadomość prawna w Kościele.

\section{Elementy świadomości prawnej}

Świadomość prawna jest kategorią socjologiczno-prawną, zatem podejmując próby definiowania świadomość prawnej wiernego w Kościele katolickim, można odwołać się do już przyjętych wskaźników wyznaczających to pojęcie. Wyróżnia się następujące części składowe świadomości prawnej: wiedza prawna i ocena prawa, postawa wobec prawa oraz postulaty wobec prawa32. Niemniej jednak w literaturze pojawiają się wątpliwości co do utrzymania tych kryteriów, wynikające z tego, że popularność badań nad świadomością prawną przypadała na lata 70. dwudziestego wieku; wówczas to wyodrębniono wskaźniki, których w ostatnich dekadach nie weryfikowano.

Stąd stawia się pytania, czy „kategorie badawcze zachowały walor adekwatności do opisywanej rzeczywistości, czy też winny zostać zastąpione nowymi"33? Zmiany społeczne w ponowoczesności skłaniają do przyjęcia pojęcia „nowej świadomości prawnej” konstruowanej na założeniu prawa - leżącego na continuum, na końcu którego jest „stara świadomość prawna” - jako alternatywnego środka realizowania w społeczeństwie potrzeb jed-

30 W. Góralski, Prawo kościelne a prawo państwowe, „Studia Płockie” 31 (2003), s. 84 .

31 W. Góralski, Prawo kościelne a prawo państwowe, art. cyt., s. 84.

32 A. Gryniuk, Świadomość prawna..., dz. cyt., s. 10.

33 Z. Cywiński, Kilka uwag o ujęciach świadomości prawnej, art. cyt., s. 22. 
nostek, będących świadomymi i samodzielnymi obywatelami ${ }^{34}$. To założenie przyjmuje pluralizm interesów społecznych. O ile jednak w prawie świeckim światopogląd ulega zmianom, to w prawie kościelnym przyjęcie innych celów nie jest możliwe. Należy bowiem pamiętać, że Kościół jest społecznością podobną do innych społeczności, ponieważ posiada strukturę, ma określone cele oraz środki do ich osiągnięcia, ale w swej naturze Kościół różni się od natury społeczności ziemskich ${ }^{35}$. Prawo w Kościele służy budowaniu wspólnoty, która, jak pisał ks. prof. Remigiusz Sobański, nie może być obojętna na trudne sytuacje życiowe, lecz z drugiej strony członkowie tej wspólnoty nie mogą ignorować jej historycznych uwarunkowań ${ }^{36}$ oraz celu, jakim jest salus animarum, niezależny od zmieniającego się zewnętrznie świata.

\subsection{Wiedza prawna adresata normy prawnej}

Za podstawowy element świadomości prawnej przyjmuje się znajomość normy prawnej. Jest ona warunkiem przestrzegania jej przez adresata normy, a także skuteczności zamierzeń ustawodawcy ${ }^{37}$. Taki pogląd jest obecny również w kanonistyce, podkreśla się znaczenie procesu komunikacyjnego między prawodawcą a odbiorcą dla efektywności prawa kanonicznego ${ }^{38}$. Prawo kanoniczne wobec wiernego „pełni [...] ważną rolę informacyjną i wpływa na kształtowanie świadomości”39. Zatem na kościelnym

34 Z. Cywiński, Kilka uwag o ujęciach świadomości prawnej, art. cyt., s. 22.

35 P. Kroczek, Prawo we wspólnocie Kościoła, [w:] Wspólnoty opisane. Zjawisko wspólnotowości w perspektywie interdyscyplinarnej, red. M. Kopczyk, Bielsko-Biała 2011, s. 53-62.

36 R. Sobański, Nauki podstawowe..., dz. cyt., s. 124-125.

37 A. Pieniążek, M. Stefaniuk, Socjologia prawa. Zarys wykładu, Warszawa 2014, s. 165 .

38 Zob. P. Kroczek, Kiedy prawo kanoniczne jest efektywne?, „Annales Canonici” 2 (2006), s. 163-177.

39 R. Sobański, Nauki podstawowe..., dz. cyt., s. 122. 
prawodawcy ciąży obowiązek poinformowania o normie prawnej osoby, do której jest skierowana ustawa kościelna.

W pierwszej kolejności należy zaznaczyć, o jaką znajomość prawa chodzi prawodawcy. Wydaje się, że określenie zakresu wiedzy kanonicznej jest bardzo trudne. Można tu odwołać się do wymagań stawianych nupturientom, dotyczących wiedzy o naturze małżeństwa katolickiego. Wiedza, jakiej się wymaga, jest określana jako pewne minimum potrzebne do podjęcia decyzji: prawodawca nie oczekuje od narzeczonych wyczerpującej wiedzy o istocie małżeństwa. Jednocześnie jednak stawia wymagania przygotowania się do małżeństwa w tzw. okresie bezpośrednim, poprzedzającym ślub ${ }^{40}$.

W literaturze prawnej zwraca się uwagę na rozróżnienie znajomości prawa teoretycznego oraz prawa w działaniu, znaczenie ma czy adresat posiada wiedzę o prawie, czy też informacje o prawie $^{41}$. Uznaje się, że stopień znajomości prawa jest uzależniony od roli jaką pełni adresat normy, w socjologii zwraca się uwagę na dwie kategorie ról związanych ze znajomością prawa, pierwszą stanowią eksperci-prawnicy, drugą laicy ${ }^{42}$. Niemniej jednak można wyróżnić także kategorię osób określanych specjalistami, które ze względu na swoją rolę mają specjalną wiedzę o prawie ${ }^{43}$. Z wymienionymi rolami wiążą się różne społeczne oczekiwania, przykładowo wobec duszpasterzy-niespecjalistów oczekuje się roztropnej postawy wobec osób zainteresowanych nieważnością małżeństwa ${ }^{44}$.

W procesie złożenia skargi na małżeństwo w sądzie kościelnym, adresatami normy według kan. 1674 Kodeksu prawa kanonicznego

\footnotetext{
40 FC 66.

41 Z. Ziembiński, S. Wronkowska, Zarys teorii..., dz. cyt., s. 199.

42 A. Gryniuk, Świadomość prawna..., dz. cyt., s. 32.

43 A. Gryniuk, Świadomość prawna..., dz. cyt., s. 21.

44 Zob. szerzej P. Kroczek, Kilka uwag kanoniczno-duszpasterskich odnośnie do orzeczenia nieważności matżeństwa, „Bielsko-Żywieckie Studia Teologiczne” 8 (2012), s. 169-18o.
} 
są małżonkowie katoliccy, również niekatoliccy, ochrzczeni i nieochrzczeni, wszyscy, których małżeństwo zostało zawarte w Kościele katolickim, a także, gdy zostało zawarte poza Kościołem wówczas sędzia kościelny rozpatruje „tylko sprawy dotyczące nieważności małżeństwa akatolików, zarówno ochrzczonych jak i nieochrzczonych, w których konieczne jest udowodnienie, wobec Kościoła katolickiego stan wolny przynajmniej jednej ze stron [...]" (zob. art. 2 DC). Takie uprawnienie posiada również rzecznik sprawiedliwości w sytuacjach, gdy nieważność została rozgłoszona, małżeństwa nie można uważnić lub nie jest to zalecane (art. 92 DC)45. Zasadniczo więc adresatem są osoby pełniące rolę eksperta-prawnika lub laika.

W kwestii znajomości prawa należy zwrócić uwagę na tzw. surogaty znajomości prawa, czyli pozaprawne dyrektywy postępowania. Należy do nich wiedza wynikająca przykładowo z innych systemów normatywnych równolegle istniejących w społeczeństwie. Zbieżność norm jest znacząca dla funkcjonowania jednostek w społeczeństwie ${ }^{46}$. Problematyczne natomiast staje się, gdy normy dotyczące tych samych faktów społecznych różnią się. Jeżeli jednostka doświadcza rozdźwięku w przekonaniach, występującego w laicyzującym się społeczeństwie, wówczas próbuje usunąć ten dysonans ${ }^{47}$. Zatem w relacji między prawem kanonicznym Kościoła katolickiego oraz polskim prawem, wierny będący uczestnikiem obu systemów prawa nie zawsze będzie potrafił prawidłowo identyfikować oba porządki ${ }^{48}$.

45 W. Kiwior, Strony procesowe, [w:] Komentarz..., dz. cyt., s. 153-155.

46 A. Gryniuk, Świadomość prawna...., dz. cyt., s. 34.

47 A. Malewski, Rozdźwięk pomiędzy uznawanymi przekonaniami i jego konsekwencje, „Studia Socjologiczne” 1 (1961), s. 63.

48 P. Zamelski, Świadomość prawna w Kościele czy świadomość Kościoła?, „Kościół i Prawo" 4 (2005), s. 28. 
W optyce tematu jest kościelna instytucja małżeństwa, na którą według kanonistów znacząco wpływa mentalność rozwodowa49, między innymi kształtuje ona społeczne przekonanie o istnieniu „rozwodów kościelnych”. Tymczasem w prawie świeckim podkreśla się społeczną doniosłość faktu błędnej znajomości prawa przez adresata normy. Sytuacja taka może pokazywać, które normy są przekraczane przez jednostki, to z kolei wskazuje prawodawcy miejsca, w których stanowione przez niego prawo jest nieefektywne albo też gdzie została zaburzona komunikacja. Błędna wiedza będzie wpływała na postawę wobec prawa, jaką przyjmie adresat, często może wiązać się z negatywnym nastawieniem, bowiem z niewiedzy adresat nie korzysta z przysługujących mu uprawnień, które mogłyby zaspokoić jego potrzeby ${ }^{50}$.

Osoby składające skargę na małżeństwo mają zróżnicowaną wiedzę na temat orzeczenia nieważności małżeństwa. Należy przyjąć, że po tego rodzaju informacje osoba sięga dopiero w okolicznościach związanych z decyzją o złożeniu skargi na małżeństwo. Istotną rolę w kształtowaniu wiedzy prawnej ma nadawca, określany też jako autor przekazu. Nadawcą prawa w Kościele katolickim jest Magisterium Kościoła, które publicznie ogłasza ustawy w organie urzędowym „Acta Apostolicae Sedis” (kan. 8 §1 KPK). Promulgacja ustawy, jak się podkreśla w kanonistyce, jest nie tylko ogłoszeniem woli prawodawcy, ale także elementem przepowiadania wiary oraz praktyki wiary ${ }^{51}$. Istotnym zadaniem Kościoła jest również podejmowanie działań popularyzujących ustawy prawne, tak aby prawo docierało do wiernych, a tym samym było bardziej efektywne ${ }^{52}$.

49 R. Sobański, Wpływ mentalności wolnych zwiq̨zków na ważność zgody matżeńskiej, „Annales Canonici” 4 (2008), s. 5-19.

50 Z. Ziembiński, S. Wronkowska, Zarys teorii ..., dz. cyt., s. 202.

51 R. Sobański, Nauki podstawowe..., dz. cyt., s. 105.

52 P. Kroczek, Kiedy prawo..., dz. cyt., s. 174. 
W literaturze przedmiotu stwierdza się także, że za przekazem normy prawnej (należy także przyjąć, że normy kanonicznej) stoi zwykle jakiś konkretny człowiek kształtujący zakres treści przekazywanych w komunikacie skierowanym do adresata normy ${ }^{53}$. W tym kontekście warto przyjrzeć się, z jakich źródeł informacji korzystali wierni Kościoła składający skargę na swoje małżeństwo. Informacje dotyczące prawa kanonicznego o nieważności małżeństwa uzyskane przez badanych respondentów pochodziły w pierwszej kolejności z mediów takich jak Internet czy też czasopisma oraz od księży z własnej parafii. Następnie ze świeckich kancelarii prawniczych zajmujących się także prawem kanonicznym, wierni także często rozmawiali ze znajomymi, którzy uczestniczyli w procesie o stwierdzenie nieważności małżeństwa. Natomiast badani rzadko zwracali się po informację do sądu biskupiego oraz sporadycznie sięgali do literatury przedmiotu. Zdarzały się także osoby, którym informacji udzielił znajomy katecheta lub znajomy ksiądz. Nie we wszystkich przypadkach - w ocenie badanych osób - uzyskana wiedza była wystarczająca, ponieważ w odpowiedzi na kolejne zadane pytanie o najlepsze według nich źródło wiedzy nie zawsze odnosili się do tych początkowo wybranych, lecz wskazywali na inne źródła. Weryfikacji poddane zostały media; połowa korzystających z tego źródła, uznała, że potrzebne informacje lepiej byłoby uzyskać w kancelarii zajmującej się prawem kościelnym lub od znajomych, którzy „przez to przeszli”. Niektórzy respondenci korzystający z wiedzy od księdza z parafii, wybierali jako lepsze inne źródła. Nieznacznie wzrosło wśród respondentów przekonanie, że sąd biskupi może być dobrym źródłem informacji.

Wobec powyższego można stwierdzić, że wierni posiadają informacje o prawie kanonicznym w zakresie orzeczenia nieważności

53 A. Gryniuk, Świadomość prawna..., dz. cyt., s. 44. 
małżeństwa z różnych źródeł, w związku z tym zakres tej wiedzy jest zróżnicowany. Warto także zwrócić uwagę na charakter tej wiedzy. Pojawia się pytanie o przekaz o małżeńskim prawie kościelnym - bez uszczerbku dla prawa kościelnego - w kancelariach prowadzących sprawy rozwodowe równocześnie z orzeczeniami o nieważności małżeństwa w Kościele katolickim. Oceny dotyczącej źródeł wiedzy o prawie kanonicznym małżeńskim respondenci dokonywali według swych subiektywnych przekonań. Nie można tu pominąć znaczącego faktu, że w odbiorze informacji adresat przeprowadza selekcję informacji, zwracając uwagę na wiadomości, które są zgodne z jego przekonaniami, interesami oraz postawami ${ }^{54}$.

\subsection{Ocena, postawa oraz postulaty wobec prawa}

Kolejnym elementem świadomości prawnej jest ocena prawa przez adresata, najczęściej rozumiana dychotomicznie, jako aprobata lub dezaprobata jakiegoś stanu rzeczy ${ }^{55}$. Kryteriami dokonywania oceny są wartości moralne czy etyczne oraz aspekty prakseologiczne. Prawo oceniane jest jako słuszne lub niesłuszne, postrzega się je także jako sprawiedliwe lub niesprawiedliwe. Oczywiście w kontekście pluralizmu społecznego pojawiają się pytania o to, jaki rodzaj moralności ma być wyznacznikiem dla prawodawcy $\mathrm{w}$ tworzeniu prawa ${ }^{56}$, $\mathrm{z}$ drugiej strony należy zapytać, według jakiej moralności ma być dokonywana przez adresata ocena prawa. W przypadku prawa kanonicznego odniesieniem jest moralność chrześcijańska, nie wyklucza to jednak sytuacji, że prawo to jest oceniane według innej moralności.

54 A. Pieniążek, M. Stefaniuk, Socjologia prawa. Zarys wykładu, Warszawa 2014, S. 172.

55 J. Nowacki, Z. Tobor, Wstęp do prawoznawstwa, Warszawa 2012, s. 16.

56 K. Frieske, Socjologia prawa, Warszawa-Poznań 2001, s. 54. 
Istotne znaczenie w formułowaniu oceny prawa według Anny Gryniuk ma wiedza jednostki o prawie: im wiedza ta jest szersza, tym bardziej ocena ma charakter refleksyjny ${ }^{57}$. W literaturze przedmiotu stwierdza się także, że większa dezinformacja adresata o prawie wiąże się z mniejszą refleksją i bardziej negatywną oceną prawa ${ }^{5}$. W odniesieniu do powyższego warto przytoczyć postawioną w literaturze tezę, dotyczącą istniejącej różnicy w ocenie prawa przez laika i prawnika-specjalistę 59 . Ocena prawa dokonywana przez osoby pełniące role niewymagające znajomości prawa częściej mają charakter oportunistyczny i prakseologiczny. Istotne znaczenie w kształtowaniu opinii jednostki ma także przebieg socjalizacji - rozumianej, tu jako prawna socjalizacja ${ }^{60}$ - oraz dotychczasowe doświadczenia z szeroko rozumianym prawem. Natomiast podkreśla się, że prawnik-specjalista jest w pewnym sensie ograniczony przez prawo $\mathrm{w}$ formułowaniu ocen, ponieważ jego wiedza kształtuje się poprzez narzucenie wartości wypracowanych w systemie normatywnym. Ten aspekt ma znaczenie w kontekście procesu komunikacyjnego, gdy prawnik przekazuje normę prawną adresatowi ${ }^{61}$.

Oceny prawa podzielono ze względu na motywy zachowania osób oraz ze względu na sposób uzasadniania tych ocen, przyjmując takie rodzaje ocen, jak krytyczno-wartościująca oraz legalistyczna. Inną perspektywą jest ocena prawa w odniesieniu jednostki do grupy; takie oceny rozpatrywane są w kategoriach

57 A. Gryniuk, Świadomość prawna...., dz. cyt., s. 63.

58 Z. Ziembiński, S. Wronkowska, Zarys teorii..., dz. cyt., s. 203.

59 A. Pieniążek, M. Stefaniuk, Socjologia prawa..., dz. cyt., s. 184.

6o W. Staśkiewicz, hasło: socjalizacja prawna, [w:] Leksykon socjologii prawa, red. A. Kociołek-Pęksa, M. Stępień, Warszawa 2013. Socjalizacja prawna jest „fragmentem procesu przyswajania przez jednostkę wartości, norm i wzorów zachowań w danej grupie umożliwiających jej adaptację do społecznych instytucji, czyli socjalizacji”, s. 325 .

61 A. Gryniuk, Świadomość prawna...., dz. cyt., s. 83. 
konformizmu oraz nonkonformizmu ${ }^{62}$. Tutaj warto odnieść się do badań nad społeczno-religijnymi postawami Polaków, bowiem można założyć, że w postawie religijnej zawiera się postawa wobec prawa kościelnego. Motywy uczestniczenia wiernych we mszy świętej ujęto w następujących kategoriach: „motywy osobowo-religijne oraz z poczucia obowiązku wobec Kościoła (podporządkowanie się instytucjonalnym oczekiwaniom Kościoła). Motywy konformistyczne, jak dostosowanie się do ogólnego zwyczaju lub do wymagań rodziny, oraz motywy pozareligijne (msza św. jest czymś innym) - zajęły dalsze miejsca"63. Według tych kategorii można także podzielić motywy badanych osób składających skargę na małżeństwo, gdyż podobne obserwacje wynikają z praktyki duszpasterskiej ${ }^{64}$.

Z oceną prawa ściśle związana jest postawa jednostki wobec prawa. Maria Borucka-Arctowa uważała, że postawa to „dyspozycja do określonego zachowania się wobec przedmiotu postawy, gdyż jest ona jednym z czynników warunkujących zachowanie się, ale sama nie jest zachowaniem"65. Według badaczy społecznych postawa oznacza „gotowość, skłonność reagowania w określony sposób na określone bodźce"66. Wyróżnia się trzy komponenty postawy: poznawczy, wzmacniający postawę, emocjonalny, który wpływa na intencję działania, czyli zachowanie osoby. Postawa jednostki w wysokim stopniu jest kształtowana przez emocje, stąd

62 A. Pieniążek, M. Stefaniuk, Socjologia prawa..., dz. cyt., s. 181.

63 Postawy religijno-społeczne 1991-2012, red. L. Adamczuk, E. Firlit, W. Zdaniewicz, Warszawa 2013, s. 54.

64 P. Kroczek, Kilka uwag kanoniczno-duszpasterskich odnośnie orzeczenia nieważności małżeństwa, „Bielsko-Żywieckie Studia Teologiczne” 13(2012), s. 169180.

65 M. Stefaniuk, hasło: postawy wobec prawa, [w:] Leksykon socjologii prawa, dz. cyt., s. 228.

66 A. N. Oppenheim, Kwestionariusze, wywiady, pomiary postaw, tłum. S. Amsterdamski, Poznań 2004, s. 204. 
w badaniach empirycznych nad postawą należy uwzględnić także nielogiczne motywy zachowania badanych, a także możliwość braku związku między różnymi postawami jednostki ${ }^{67}$.

W literaturze przedmiotu wyróżnia się różne rodzaje postaw związanych ze stosowaniem prawa. Pierwszą z nich jest postawa oportunistyczna, w której motywacja do działania wynika z obawy przed sankcjami lub wiąże się z szansą uzyskania nagrody; oportunista w określonej sytuacji poszukuje najkorzystniejszych dla siebie możliwości zachowania. Zasady moralne nie są wyznacznikiem działania dla oportunisty, natomiast mogą być takimi dla konformisty - dla postawy jednostki związanej z odniesieniem do znaczącej dla niej grupy. Jednostka przestrzega norm prawnych wówczas, gdy jest to zgodne z opinią innych członków grupy, lub nie przestrzega prawa, gdy członkowie grupy także go nie przestrzegają. Zachowania konformistyczne wynikają z „wewnętrznego punktu widzenia”, gdy motywacja jest zróżnicowana lub nieumotywowana, nazwana także bezrefleksyjną ${ }^{68}$. Ostatnia wśród wymienianych jest postawa legalizmu związana z gotowością przestrzegania normy wyłącznie ze względu na to, że jest to prawo. Postawa ta jest indyferentna wobec moralności ${ }^{69}$.

Początkowo jednak w socjologii prawa rozróżniano postawy na zasadniczą oraz celowościową. Uważa się, że kategorie te nawiązywały do koncepcji Leona Petrażyckiego dotyczącej motywacji zasadniczej oraz celowościowej. Adam Podgórecki, kontynuator myśli Petrażyckiego postawę zasadniczą opisywał jako spontaniczną reakcję związaną z emocjami, w której jednostka podejmuje decyzję w odniesieniu do ogólnych zasad. Natomiast w postawie celowościowej jednostka dokonuje refleksji - uwarunkowanej

67 A. N. Oppenheim, Kwestionariusze, wywiady, pomiary postaw, dz. cyt., s. 204.

68 A. Podgórecki, Poglądy społeczeństwa polskiego na moralność i prawo, Warszawa 1971, s. 27.

69 Z. Ziembiński, S. Wronkowska, Zarys teorii..., dz. cyt., s. 204. 
posiadaną wiedzą - nad konsekwencjami możliwych działań. Ten typ postawy jest charakterystyczny dla zmieniającego się społeczeństwa $^{70}$. Stwierdzenie to związane było z socjalistycznymi zmianami ustroju społeczeństwa polskiego, stało się jednak coraz bardziej adekwatne dla społeczeństwa poindustrialnego, nazywanego „społeczeństwem ryzyka”71, w którym postawa jednostki w stosunku do różnych instytucji nowoczesności jest powiązana z poczuciem bezpieczeństwa. Jednostka późnej nowoczesności kształtuje swoją biografię refleksyjnie, lecz ta refleksyjność, „oznacza[jąca] systematyczne poddawanie rewizji ze względu na nowo zdobyte wiadomości lub nabytą wiedzę większość zachowań wobec ludzi [...]", dotyczy także instytucji życia społecznego ${ }^{72}$. Współcześnie zatem między prawem stanowionym przez ustawodawcę i oceniającym go odbiorcą zachodzi relacja, co umożliwia swobodniejsze formułowanie postulatów zmian w prawie przez odbiorców prawa oczekujących, że zostaną one przyjęte.

\section{Zakończenie}

W świetle powyższego zaskarżenie małżeństwa w Kościele można ująć jako złożony proces decyzyjny jednostki, którego istotnymi elementami są zarówno świadomość prawna osoby, jak i jej motywacja. Poszukiwanie prawdy o swoim małżeństwie przez wiernych rozwiedzionych należy rozumieć jako obowiązek, który powinni podejmować wspólnie małżonkowie oraz Kościół. Niewątpliwie relacje między prawodawcą a adresatem prawa ulegają zmianie we współczesnym społeczeństwie, obserwuje się wzrost świadomości prawnej wśród wiernych w zakresie kanonicznego prawa

70 A. Podgórecki, Poglądy społeczeństwa..., dz. cyt., s. 21 i s. 53.

71 U. Beck, Społeczeństwo ryzyka. W drodze do innej nowoczesności, tłum.

S. Cieśla, Warszawa 2002.

72 A. Giddens, Nowoczesność i tożsamość, tłum. A. Szulżycka, Warszawa 2012, s. 36 . 
małżeńskiego, czego przykładem jest ilość składanych skarg w sądzie kościelnym, jednak rodzą się wątpliwości co do tego, czy prawo to jest odczytywane zgodnie $\mathrm{z}$ wolą prawodawcy oraz $\mathrm{w}$ jakim stopniu na ten proces komunikacji wpływa świeckie prawo małżeńskie. Zainteresowanie świadomością prawną wiernego w Kościele wymaga uwzględnienia także świadomości moralnej czy też świadomości wiary, ponieważ tylko w perspektywie teologicznej może być ono właściwie rozumiane i stosowane przez wiernych. Zbadanie świadomości prawnej wiernego ma znaczenie zatem dla celów duszpasterskich. Wobec powyższego można postulować o taki przekaz dotyczący procesu badania ważności małżeństwa w Kościele, który będzie ujmował zarówno jego stronę teologiczną, jak i wymiar prawny.

SUMMARY

\section{Legal awareness and motivation of complainants on your marriage}

The article presents the issue of legal awareness of the divorced Catholic who take legal steps to clarify their canonical situation in the Church by asking a church Tribunal to declare their marriage annulled and be free to marry again. The motives for doing this can be of moral and legal character. For the application of canon law, it seems to be the most important the moral motivation, which later on evolves the legal motivation. The kind or source of reasons for the actions in question, in fact, do not have any impact on the entire process or the result of it. But taking into account the social changes of the forms of family life deviating from the Christian model of marriage, it is important to look at the legal awareness of the faithful, which could reveal how the people interpret and apply the marital canon 
law. The legal awareness reflects the relationship between the legislator and the addressee of the legal provisions.

Keywords: legal awareness of the faithful, legal motivation, marriage annulled

U. Miernik, Świadomość prawna a motywacje osób składających skargę na swoje matżeństwo, [w:] Znaczenie wiary dla małżeństwa: w kierunku zmiany prawa, red. Piotr Kroczek, Kraków 2016, s. 83-106 (Annales Canonici Monographiae, 4).

DOI: http://dx.doi.org/10.15633/9788374385220.o6 